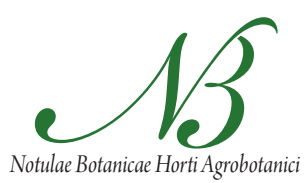

Cluj-Napoca

\title{
Influence of the Management on the Phytocoenotic Biodiversity of Some Romanian Representative Grassland Types
}

\author{
Vasile VÎNTU', Costel SAMUIL', Ioan ROTAR², Alexandru MOISUC 33 , Iosif RAZEC 4 \\ ${ }^{1}$ University of Agricultural Sciences and Veterinary Medicine, Iasi, 3 M. Sadoveanu Aleea, 700490, Romania; vvintu@uaiasi.ro, csamuil@uaiasi.ro \\ ${ }^{2}$ University of Agricultural Sciences and Veterinary Medicine, Cluj-Napoca,3-5 Mănăştur, 400372, Romania; rotarioan52@yahoo.fr \\ ${ }^{3}$ Banat University of Agricultural Sciences and Veterinary Medicine, Timisoara, 119 Aradului Calea, 300645, Romania; alex_moisuc@yahoo.de \\ ${ }^{4}$ Institute of Research-Development for Grasslands, Brasov, 5 Cucului, 500128, Romania; razeci@yahoo.com
}

\begin{abstract}
The pastoral area of Romania, covering of over 4.8 million ha, has been influenced, over the last decades, by natural and human factors, which affect the normal functioning of the grassland ecosystem. The aim of this paper is to point out the dynamics of phytocoenotic biodiversity, as a result of applying grassland technical measures, in order to improve the yield and quality of grassland ecosystems with minimum effects on the environment. Therefore, the main aim of our study is to establish a positive relationship between biodiversity and the optimum quantity of organic fertilizers, which would improve the quality and quantity of the yield, without diminishing the floristic biodiversity. In the case of the studied grasslands, the phytocenotic biodiversity is influenced by the type of fertilization, the used rates and by the soil and climatic conditions. These grasslands may be improved by manure fertilization and reasonable usage, if proper management is applied. In Gradinari, Caras-Severin county, the dominant species are Festuca rupicola and Calamagrostis epigeios, in Magurele, Brasov county, Agrostis capillaris, Festuca pratensis, Poa pratensis and Trifolium repens, and in Pojorata, Suceava county, Agrostis capillaris, Trisetum flavescens, Trifolium repens and T. pratense species. The highest number of identified species (43) has been recorded by the meadow made up of Agrostis capillaris and Festuca rubra, from Pojorata, Suceava county.
\end{abstract}

Keywords: forbs, grasses, legumes, organic fertilization, vegetal canopy

\section{Introduction}

Biodiversity has become one of the main concerns of our world, because modern farming, forestry and meadow culture focussed, in these latter years, on developing methods and proceedings for achieving high productions, without being interested in the quality of produces or environment health. Among the factors threatening biodiversity, one enlists human activities, high pressures on natural resources, division, change or even destruction of habitats, excessive use of pesticides, chemical fertilizers etc. (Weigelt et al., 2009). Nowadays, many specialists are concerned with adapting the technologies of fodder production to the new economic and ecological requirements, whilst the maintaining of biodiversity occupies an important place (Belesky et al. 2002; Duelli, 1997; Elsaesser et al., 2008; Hopkins et al., 1999; Jeangros, 2002; Nilsson, 2009; Peeters et al., 2004; Rotar et al., 2010; Vîntu et al. 2003; 2008). Previous research, done in different climatic and managerial conditions proved that there is a relationship between biodiversity and pastures productivity. The latter is influenced by the soils fertility, chemical reaction, and usage, intensity of grazing, altitude, amount and distribution rainfalls (Dolek and Gezer, 2002; Dumont et al., 2007; Hector and Loreau, 2005; Isselstein et al., 2007; Ko- pec et al., 2010; Metera et al., 2010; Mosquera-Losada et al., 2009; Soder et al., 2007; Tilman et al., 1996).

The objectifs of this paper are to establish the influence of the management on the rate of species in the structure of vegetation, and dominant species in the vegetal canopy; to establish the influence of the type of fertilization on the dynamics of biodiversity and to establish the best dose of fertilization in order to improve the production on the permanent grassland.

For attaining the paper's objectives, the main meadow ecosystems assessed have been qualitatively and quantitatively and the evolution of vegetal canopy has been diagnosed according to the management of some meadow types found under different ecological conditions.

\section{Materials and methods}

For the study of the meadows' vegetation, we have used the geo-botanical method (Braun Blanquet, 1964) by carrying out observations on experimental variants and replicates during the first cycle of vegetation.

The species included in the floristic catalogues of the areas under study have been classified into several categories, according to their dominance: dominant species (coverage degree of 60-100\%), co-dominant species (coverage degree of $25-40 \%$ ) and indicator species, with a low presence in 
Tab. 1. Experimental variants in the studied sites

\begin{tabular}{|c|c|c|c|}
\hline Variants & Gradinari, Caras-Severin county & Magurele, Brasov county & Pojorata, Suceava county \\
\hline 1 & unfertilized control & unfertilized control & unfertilized control \\
\hline 2 & $\begin{array}{l}10 \mathrm{t} / \text { ha manure, applied } \\
\text { once in } 3 \text { years }\end{array}$ & $\begin{array}{l}20 \mathrm{t} / \text { ha manure every } 2 \text { years, application } \\
\text { in autumn and usage as hayfield }\end{array}$ & $10 \mathrm{t} /$ ha manure every year \\
\hline 3 & $\begin{array}{l}20 \mathrm{t} / \text { ha manure, applied } \\
\text { once in } 3 \text { years }\end{array}$ & $\begin{array}{l}20 \mathrm{t} / \mathrm{ha} \text { manure every } 2 \text { years, application in } \\
\text { autumn and usage by simulation grazing }\end{array}$ & 20 t/ha manure every 2 years \\
\hline 4 & $\begin{array}{l}30 \mathrm{t} / \text { ha manure, applied } \\
\text { once in } 3 \text { years }\end{array}$ & $\begin{array}{l}20 \text { t/ha manure every } 2 \text { years, application } \\
\text { in spring and usage as hayfield }\end{array}$ & 30 t/ha manure every 3 years \\
\hline 5 & $\begin{array}{l}40 \mathrm{t} / \text { ha manure, applied } \\
\text { once in } 3 \text { years }\end{array}$ & $\begin{array}{l}20 \mathrm{t} / \mathrm{ha} \text { manure every } 2 \text { years, application in } \\
\text { spring and usage by simulation grazing }\end{array}$ & $\begin{array}{l}20 \mathrm{t} / \mathrm{ha} \text { manure in the first year }+10 \\
\mathrm{t} / \mathrm{ha} \text { manure in the second year }+0 \\
\mathrm{t} / \mathrm{ha} \text { manure in the third year }\end{array}$ \\
\hline 6 & $10 \mathrm{t} / \mathrm{ha}$ manure, applied each year & $\begin{array}{l}40 \mathrm{t} / \mathrm{ha} \text { manure every } 4 \text { years, application } \\
\text { in autumn and usage as hayfield }\end{array}$ & $\begin{array}{c}20 \mathrm{t} / \mathrm{ha} \text { manure in the first year }+0 \\
\mathrm{t} / \mathrm{ha} \text { in the second year+10 } \mathrm{t} / \\
\text { ha manure in the third year }\end{array}$ \\
\hline 7 & $20 \mathrm{t} / \mathrm{ha}$ manure, applied each year & $\begin{array}{l}40 \mathrm{t} / \mathrm{ha} \text { manure every } 4 \text { years, application in } \\
\text { autumn and usage by simulation grazing }\end{array}$ & $\begin{array}{l}20 \mathrm{t} / \mathrm{ha} \text { manure in the first year }+10 \\
\mathrm{t} / \mathrm{ha} \text { manure in the second year }+10 \\
\mathrm{t} / \mathrm{ha} \text { manure in the third year }\end{array}$ \\
\hline 8 & $30 \mathrm{t} / \mathrm{ha}$ manure, applied each year & $\begin{array}{l}40 \mathrm{t} / \text { ha manure every } 4 \text { years, application } \\
\text { in spring and usage as hayfield }\end{array}$ & $\begin{array}{l}10 \mathrm{t} / \mathrm{ha} \text { manure in the first year }+20 \\
\mathrm{t} / \mathrm{ha} \text { manure in the second year }+10 \\
\mathrm{t} / \mathrm{ha} \text { manure in the third year }\end{array}$ \\
\hline 9 & 40 t/ha manure, applied each year & $\begin{array}{l}40 \mathrm{t} / \mathrm{ha} \text { manure every } 4 \text { years, application in } \\
\text { spring and usage by simulation grazing }\end{array}$ & 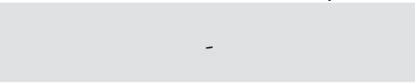 \\
\hline 10 & $\begin{array}{l}40 \mathrm{t} / \mathrm{ha} \text { manure, applied every } 3 \text { year } \\
+10 \mathrm{t} / \mathrm{ha} \text { manure, applied each year }\end{array}$ & $\begin{array}{l}60 \text { t/ha manure every } 4 \text { years, application } \\
\text { in autumn and usage as hayfield }\end{array}$ & - \\
\hline 11 & e & $\begin{array}{l}60 \mathrm{t} / \mathrm{ha} \text { manure every } 4 \text { years, application in } \\
\text { autumn and usage by simulation grazing }\end{array}$ & - \\
\hline 12 & - & $\begin{array}{l}60 \mathrm{t} / \text { ha manure every } 4 \text { years, application } \\
\text { in spring and usage as hayfield }\end{array}$ & - \\
\hline 13 & - & $\begin{array}{l}60 \mathrm{t} / \mathrm{ha} \text { manure every } 4 \text { years, application in } \\
\text { spring and usage by simulation grazing }\end{array}$ & - \\
\hline
\end{tabular}

the vegetal canopy, still expressing the specific features of the ecological factors (acid or alkaline soils, fertile or poor soils in nutrients, moist or dry soils etc.).

The studies have been carried out in Gradinari, CarasSeverin county, Magurele, Brasov country and Pojorata, Suceava county (Romania), and they have been organized in monofactorial experiments, in randomized blocks with four replicates, as presented in Tab. 1. The manure was applied manually in very early spring, in March, at the beginning of grass growth.

The experimental variants were differed from location to location according to the variation of the manure dosis used in order to fertilize the natural pastures of the area by the animal growers.

In Gradinari and Pojorata, the meadows was mowed in haystacks, at the level of inflorescences formation at the dominant grasses, while, in Magurele, half of the experimental variants have been harvested by mowing, as haystacks, as if by simulating grazing, mowed at a height of $15-18 \mathrm{~cm}$ of dominant plants.

\section{Results and discussion}

The experiments presented in this paper have been conducted on representative meadows, found under di- verse ecological conditions from three sites and spread in two vegetation zones: the forest-steppe zone/level with one site (Gradinari, Caras-Severin county), the nemoral level with two sites (Magurele, Brasov county, Pojorata, Suceava county) (Fig. 1).

The data presented in Tab. 2 have shown that the mean multiannual temperatures recorded values that vary between 6.5 and $10.4^{\circ} \mathrm{C}$, and the rainfall regime that influenced greatly the productivity and composition of the vegetal canopy registred mean annual values comprised between 700 and $836.0 \mathrm{~mm}$. The analysed meadow ecosystems are located at average heights varying between 195 and $707 \mathrm{~m}$.

Tab. 2. Soil and ecological characteristics of the studied sites

\begin{tabular}{ccccc}
\hline Site & $\begin{array}{c}\text { Mean } \\
\text { temperature } \\
\left({ }^{\circ} \mathrm{C}\right)\end{array}$ & $\begin{array}{c}\text { Mean } \\
\text { rainfall } \\
(\mathrm{mm})\end{array}$ & $\begin{array}{c}\text { Average } \\
\text { altitude } \\
(\mathrm{m})\end{array}$ & Soil type \\
\hline $\begin{array}{c}\text { Gradinari- } \\
\text { Caras- } \\
\text { Severin }\end{array}$ & 10.4 & 836 & 195 & $\begin{array}{c}\text { Moderately } \\
\text { eroded cambic } \\
\text { chernozem }\end{array}$ \\
$\begin{array}{c}\text { Magurele- } \\
\text { Brasov }\end{array}$ & 7.2 & 700 & 600 & $\begin{array}{c}\text { Dark eu- } \\
\text { mesobasic }\end{array}$ \\
$\begin{array}{c}\text { Pojorata- } \\
\text { Suceava }\end{array}$ & 6.5 & 708.7 & 707 & $\begin{array}{c}\text { Dark eu- } \\
\text { mesobasic }\end{array}$ \\
\hline
\end{tabular}




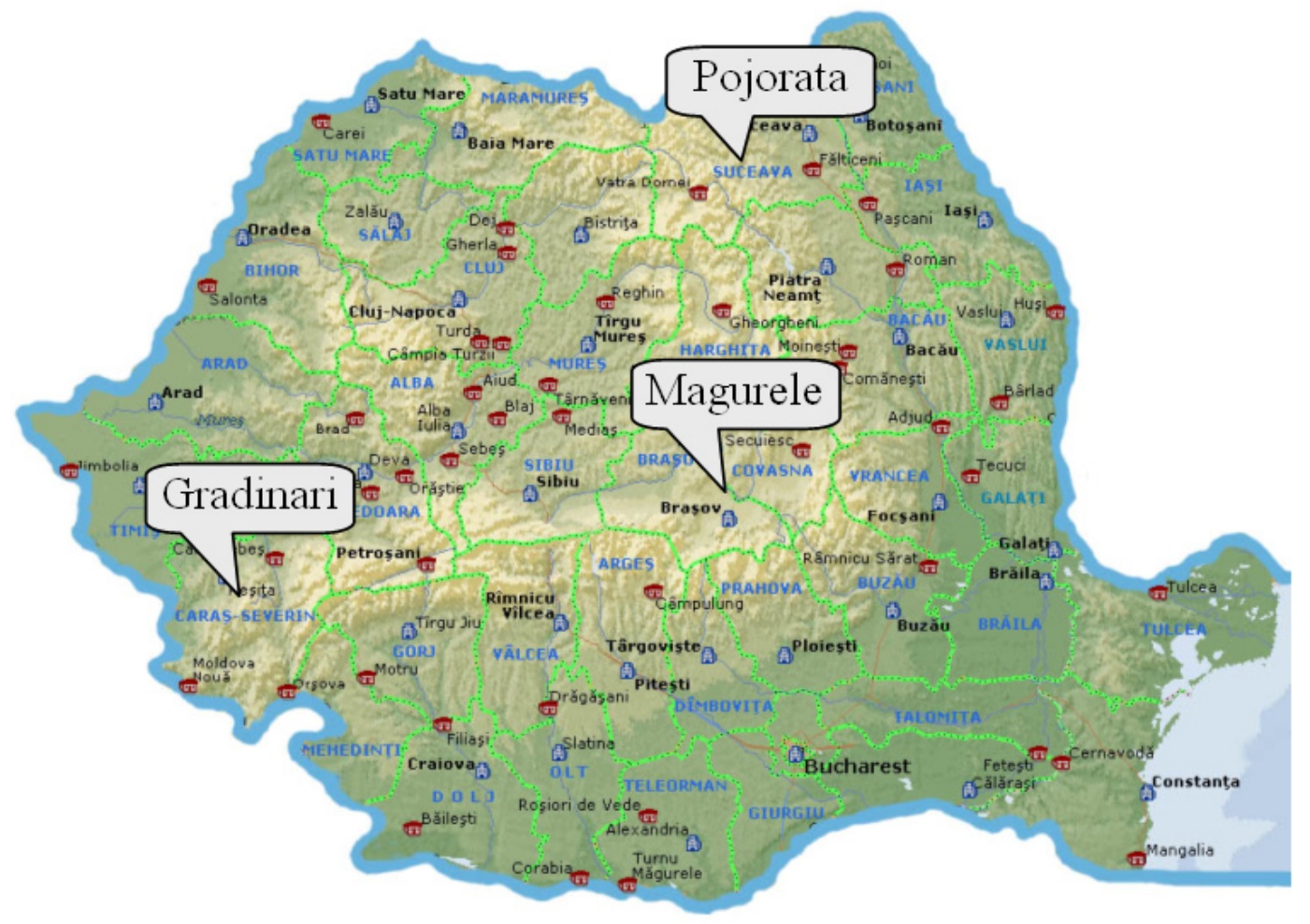

Fig. 1. Location of the three sites on Romanian territory

The meadow vegetation from the Gradinari area presented a $100 \%$ coverage degree; the dominant species in the vegetal canopy was Festuca rupicola with a specific coverage of $16-66 \%$ when fertilised, compared with $33 \%$ in the unfertilized control. The co-dominant species in the Gradinari area is Calamagrostis epigeios, with a specific coverage of up to $49 \%$ at a fertilization rate of $20 \mathrm{t} / \mathrm{ha}$ manure, applied once in 3 years. The grass species had a significant contribution to the vegetal canopy, varying between 63$89 \%$. Data analysis recorded a diminishing of the share of the Calamagrostis epigeios species, with low fodder value, in the majority of fertilised variants. The legums species presented very low participation in the vegetal canopy, with a $1-2 \%$ coverage degree, but the forbs contributed at the vegetal canopy formation with $11-36 \%$, of major importance being Filipendula vulgaris and Achillea millefolium (Tab. 3). Manure fertilisation, under the terrain and climatic conditions of the Gradinari area brought no important changes in the legumes share, but determined a rise in weeds presence in five of the fertilised variants and a diminishing of their presence in only two of the studied variants (from $22 \%$ to $11 \%$ in V7, respectively $12 \%$ in V9). The chemical reaction of the vegetal canopy at fertilisation depends, among others, on the soil type and climatic conditions (Hector, 2005; Kopec, 2010). The vegetal canopy of this meadow was made up of 31 species, of which $29 \%$ belong to the grass family, $6 \%$ to Cyperaceae and Juncaceae and $10 \%$ to legumes, the rest of $55 \%$ being represented by the species belonging to other botanical families.

As for the number of species, which form the vegetal canopy of the Gradinari meadow, we have identified 31 species, 9 of them belonging to the grass family, 3 to legumes, 2 to Cyperaceae and Juncaceae and 19 species to other botanical families (forbs).

In Magurele, Brasov county, the organic fertilization has especially influenced the floristic composition, 20-31 species being found on average in the vegetal canopy. The grass species participated in the vegetal canopy with 61$72 \%$, the legumes, with $13-29 \%$ and the forbs, with $7-18 \%$. Tab. 4 shows the increase in the presence of Poa pratensis species by 15-30\% and of Festuca pratensis species, by 15$20 \%$, according to different manners of usage. An increase in the presence of valuable grasses was also found: Dactylis glomerata (until up to $10 \%$ in V10) and Arrhenatherum elatius, in some fertilization variants (2-3\% in V2-V4), as well as Festuca pratensis and Poa pratensis, to the prejudice of Festuca rubra and Agrostis capillaris species, whose contribution to the composition of the vegetal canopy decreased visibly. Therefore, the increase of soil fertility determined a change of meadow dominance and also an increase in valuable species share, with high productivity, aspects that have also been identified by Mosquera-Losada (2009), Tilman (1996).

Within the species of legumes, we have noticed their increased presence in the vegetal canopy, until 13-29\%. Among all the variants, the dominant species, was Trifolium repens, with a growth of $12-22 \%$ at fertilization rates, compared with only $2 \%$ at the unfertilized control, followed by Trifolium pratense 2-5\%, Lotus corniculatus 1-3\% and Medicago lupulina 2-7\%.

Under the eco-climatic conditions of Magurele, manure fertilization has determined an important growth 
Tab. 3. Dynamics of phytocoenotic biodiversity on Festuca rupicola grassland from Gradinari, Caras-Severin county (\%)

\begin{tabular}{|c|c|c|c|c|c|c|c|c|c|c|}
\hline Species & $\mathrm{V}_{1}$ & $\mathrm{~V}_{2}$ & $\mathrm{~V}_{3}$ & $\mathrm{~V}_{4}$ & $\mathrm{~V}_{5}$ & $\mathrm{~V}_{6}$ & $\mathrm{~V}_{7}$ & $\mathrm{~V}_{8}$ & $\mathrm{~V}_{9}$ & $\mathrm{~V}_{1}$ \\
\hline Festuca rupicola & 33 & 32 & 16 & 49 & 66 & 47 & 46 & 15 & 49 & 47 \\
\hline Poapratensis & 15 & + & + & + & & + & + & + & & + \\
\hline Calamagrostis epigeios & 30 & 46 & 49 & 16 & 15 & 32 & 14 & 45 & + & 29 \\
\hline Anthoxanthum odoratum & + & + & + & + & + & + & + & + & 1 & + \\
\hline Bromus inermis & & & + & + & & + & 29 & 3 & 15 & \\
\hline Briza media & & & + & & & + & & & & \\
\hline Brachypodium pinnatum & & & + & & + & & & + & + & + \\
\hline Alopecurus pratensis & & + & & 12 & & & + & & 13 & \\
\hline Bromus mollis & & & & & + & + & & & & + \\
\hline Grasses & 78 & 78 & 65 & 77 & 81 & 79 & 89 & 63 & 78 & 76 \\
\hline Trifolium repens & & & & + & + & & & 1 & + & \\
\hline Lotus corniculatus & 1 & + & 2 & + & + & 1 & + & + & + & 1 \\
\hline Genista tinctoria & & & + & & & & + & & & + \\
\hline Legumes & 1 & - & 2 & - & - & 1 & - & 1 & - & 1 \\
\hline Luzula luzuloides & + & & & & & + & & & & \\
\hline Carexpraecox & & & & + & & & + & & + & + \\
\hline Filipendula vulgaris & 1 & 15 & 29 & 5 & 14 & 16 & 5 & 15 & 5 & 14 \\
\hline Plantago media & 1 & + & 2 & + & 1 & 1 & 1 & + & + & 1 \\
\hline Cichorium intybus & + & + & & & & & & & & + \\
\hline Agrimonia eupatoria & + & 2 & + & 7 & + & + & 2 & + & + & 1 \\
\hline Achillea millefolium & 16 & 2 & + & 2 & 1 & & & 14 & 3 & 4 \\
\hline Rosa gallica & + & + & & + & & 1 & 1 & & & + \\
\hline Ranunculus acris & + & & + & + & + & & & + & 1 & \\
\hline Thymus serpyllum & 1 & 1 & & + & 1 & 1 & & 1 & 1 & 1 \\
\hline Crataegus monogyna & & + & & & & & + & & & \\
\hline Galium molugo & 1 & + & + & & & + & & + & & 1 \\
\hline Euphorbia cyparissias & & & 1 & 9 & 1 & & + & 1 & 1 & + \\
\hline Hieracium pilosella & & 1 & & & + & & & + & & \\
\hline Linaria genistifolia & & & 1 & & + & 1 & 1 & & + & 1 \\
\hline Pastinaca sativa & & & + & & & + & & & & + \\
\hline Origanum vulgare & & & & & & + & & & & \\
\hline Prunella vulgaris & 1 & 1 & & + & 1 & & 1 & 2 & 1 & + \\
\hline Scabiosa ochroleuca & & & + & & & & & & & + \\
\hline Forbs & 21 & 22 & 33 & 33 & 19 & 20 & 11 & 36 & 12 & 23 \\
\hline Species number & 16 & 17 & 20 & 17 & 17 & 18 & 17 & 18 & 18 & 22 \\
\hline
\end{tabular}

of legumes rate within the vegetal canopy, improving the quality of fodder, in all of the studied variants, confirming thus the hypothesis of a strong link between plants and the environmental conditions (Kopec, 2010; Hopkins, 1999; Metera, 2010).

The forbs are of reduced importance in the formation of biomass; still, they include a relatively high number of species (10-14), some of which can be used as fodder: Achillea millefolium, Bellis perennis, Plantago lanceolata, Taraxacum officinale, Convolvulus arvensis, whereas other are harmful to meadows: Cirsium arvense, Colchicum autumnale and Ranunculus acris.

In Pojorata, Suceava county, the organic fertilization had a positive influence on the floristic composition, were 33-40 species have been found in the vegetal canopy; the percentage of grasses was of $32-43 \%$, legumes, $27-36 \%$ and that of plants belonging to the diverse group, varied be- tween $21-32 \%$. Data from Tab. 5 show the increased presence of legume species, from $19 \%$ (control) to $27-36 \%$ (V6, respectively V4 si V8), especially Trifolium repens, T. pratense and Lotus corniculatus. The group of forbs was largely present in the formation of the biomass (20 -29 species), some of them having fodder value (Achillea millefolium, Plantago media P. lanceolata, Taraxacum offcinale) and others without fodder value (Chrysanthemum leucanthemum Filipendula hexapetala, Prunella vulgaris), or even being toxic (Colchicum autumnale).

\section{Conclusions}

The management of permanent grasslands, in terms of usage, type and intensity of fertilization and method of control has a great influence on phytocoenotic biodiversity, on the rate of species in the structure of vegetation, 
Tab. 4. Dynamics of phytocoenotic biodiversity on Agrostis capillaris grassland from Magurele, Brasov county (\%)

\begin{tabular}{|c|c|c|c|c|c|c|c|c|c|c|c|c|c|}
\hline Species & $\mathrm{V}_{1}$ & $\mathrm{~V}_{2}$ & $\mathrm{~V}_{3}$ & $\mathrm{~V}_{4}$ & $\mathrm{~V}_{5}$ & $\mathrm{~V}_{6}$ & $\mathrm{~V}_{7}$ & $\mathrm{~V}_{8}$ & $\mathrm{~V}_{9}$ & $\mathrm{~V}_{10}$ & $\mathrm{~V}_{11}$ & $\mathrm{~V}_{12}$ & $\mathrm{~V}_{13}$ \\
\hline Agrostis capillaris & 38 & 13 & 15 & 15 & 30 & 20 & 25 & 24 & 20 & 19 & 15 & 15 & 20 \\
\hline Festuca rubra & 5 & - & + & - & - & + & + & + & - & - & - & - & - \\
\hline Festuca pratensis & 6 & 15 & 15 & 15 & 15 & 14 & 20 & 15 & 20 & 20 & 15 & 20 & 15 \\
\hline Dactylis glomerata & 3 & 4 & 5 & 5 & 2 & 5 & 2 & + & 2 & 10 & 5 & 5 & 4 \\
\hline Cynosurus cristatus & 8 & - & 1 & + & + & - & - & - & - & - & - & - & - \\
\hline Holcus lanatus & 2 & + & + & + & + & - & + & - & - & - & 2 & - & - \\
\hline Arrhenatherum elatius & + & 3 & 2 & 2 & + & + & + & + & 1 & - & - & - & - \\
\hline Phleum pratense & 5 & + & + & - & + & - & + & - & - & + & - & - & - \\
\hline Bromus mollis & - & + & + & + & - & - & + & 5 & 5 & + & 3 & 3 & 2 \\
\hline Anthoxanthum odoratum & 1 & + & + & + & + & - & + & - & - & - & - & + & + \\
\hline Poapratensis & 4 & 25 & 30 & 25 & 20 & 25 & 25 & 20 & 15 & 15 & 25 & 20 & 20 \\
\hline Grasses & 72 & 60 & 68 & 62 & 67 & 69 & 62 & 64 & 63 & 64 & 65 & 63 & 61 \\
\hline Trifolium repens & 2 & 22 & 20 & 15 & 15 & 15 & 20 & 15 & 20 & 15 & 20 & 12 & 18 \\
\hline Trifolium pratense & 7 & + & 2 & 5 & 2 & 2 & 3 & 2 & 2 & 2 & 3 & 2 & 3 \\
\hline Lotus corniculatus & 3 & 1 & + & + & 2 & 1 & 2 & + & 2 & 1 & 3 & 2 & 1 \\
\hline Medicago lupulina & 1 & 7 & 3 & 7 & 5 & 3 & 2 & 4 & 5 & + & - & 2 & 2 \\
\hline Lathyrussp. & - & - & - & - & - & - & - & + & - & - & - & - & - \\
\hline Vicia cracca & - & - & - & - & + & + & + & 1 & - & + & - & 2 & + \\
\hline Legumes & 13 & 30 & 25 & 27 & 24 & 21 & 27 & 22 & 29 & 18 & 26 & 20 & 24 \\
\hline Achillea millefolium & 4 & 2 & 1 & 2 & 2 & 4 & 2 & 2 & 2 & 5 & 2 & 3 & 3 \\
\hline Chrysanthemum sp. & + & + & - & 1 & 1 & + & + & 1 & - & 1 & + & 1 & + \\
\hline Stellaria graminea & + & + & 1 & + & 1 & + & + & 1 & 1 & 1 & 1 & 1 & + \\
\hline Veronica chamaedris & 2 & + & 1 & 1 & + & + & 2 & 2 & - & 2 & 1 & 2 & 1 \\
\hline Cirsium arvense & - & - & - & - & + & + & - & - & - & - & - & - & - \\
\hline Cichorium intybus & - & 1 & + & 1 & - & + & - & - & - & - & 1 & - & - \\
\hline Prunella vulgaris & 1 & - & 1 & + & + & + & 1 & 1 & - & 1 & + & 1 & 1 \\
\hline Colchicum autumnale & - & - & - & - & + & - & - & + & - & - & - & + & - \\
\hline Alchemilla ternata & 1 & + & + & + & + & - & + & + & + & + & - & 1 & 1 \\
\hline Leontodon autumnalis & - & + & - & + & 1 & - & - & - & + & + & - & - & 1 \\
\hline Galium aparine & 2 & + & + & 2 & 1 & + & + & - & + & 3 & 1 & 2 & 2 \\
\hline Rumex crispus & - & - & + & - & + & - & - & + & - & - & - & - & \\
\hline Taraxacum officinalis & 3 & 3 & + & 2 & 3 & 4 & 3 & 2 & 2 & 3 & 1 & 1 & 3 \\
\hline Bellis perennis & + & 1 & + & + & + & + & 1 & 1 & 1 & + & + & + & + \\
\hline Planatago lanceolata & 1 & 2 & 2 & 1 & + & 2 & 1 & 2 & 2 & 1 & 1 & 2 & 2 \\
\hline Convolvulus arvensis & + & 1 & - & + & + & + & - & 2 & - & - & 1 & 2 & - \\
\hline Ranunculus acris & + & + & + & 1 & + & + & - & - & - & 1 & - & - & \\
\hline Arctium lappa & - & - & - & + & - & + & - & - & + & - & - & - & \\
\hline Hyeracium pilosella & 1 & - & - & - & + & - & + & + & - & - & - & - & \\
\hline Matricaria inodora & - & - & 1 & - & - & - & 1 & - & + & - & - & 1 & 1 \\
\hline Forbs & 15 & 10 & 7 & 11 & 9 & 10 & 11 & 14 & 8 & 18 & 9 & 17 & 15 \\
\hline Species number & 27 & 25 & 28 & 28 & 31 & 25 & 27 & 26 & 20 & 23 & 20 & 24 & 23 \\
\hline
\end{tabular}

and dominant species in the vegetal canopy. In the three experimental sites, three representative types of natural grasslands with a very various floristic composition have been studied. In Gradinari, Caras-Severin county, Festuca rupicola and Calamagrostis epigeios are the dominant species, in Magurele, Brasov county, Agrostis capillaris, Festuca pratensis, Poa pratensis and Trifolium repens, and in Pojorata, Suceava county, our study has identified the Agrostis capillaris, Trisetum flavescens, Trifolium repens and T. pratense species. The highest number of identified species (43) has been recorded by meadow made up of Agrostis capillaris and Festuca rubra, from Pojorata, Suceava county. The high dynamics of biodiversity is influenced by the type of fertilization, the quantities of fertilizers and by soil and climatic conditions. These grasslands may be improved by manure fertilization and the reasonable utilization, if and only proper management is applied. From the point of view of the biodiversity index, the studied meadows have high phytocoenotic diversity, the dominant species being the ones with closely related population stocks. 
Tab. 5. Dynamics of phytocoenotic biodiversity on Agrostis capillaris and Festuca rubra meadow from Pojorata, Suceava county (\%)

\begin{tabular}{|c|c|c|c|c|c|c|c|c|}
\hline Species & $\mathrm{V}_{1}$ & $\mathrm{~V}_{2}$ & $\mathrm{~V}_{3}$ & $\mathrm{~V}_{4}$ & $\mathrm{~V}_{5}$ & $V_{6}$ & $\mathrm{~V}_{7}$ & $\mathrm{~V}_{8}$ \\
\hline Agrostis capillaris & 19 & 13 & 14 & 11 & 10 & 10 & 13 & 12 \\
\hline Festuca rubra & 7 & 3 & 4 & 3 & 2 & 2 & 2 & 2 \\
\hline Festuca pratensis & 1 & 1 & 1 & + & + & 1 & 1 & 1 \\
\hline Dactylis glomerata & 3 & + & 2 & 2 & 1 & 7 & + & 1 \\
\hline Cynosurus cristatus & 4 & 10 & 5 & 5 & 4 & 5 & 3 & 5 \\
\hline Holcus lanatus & 1 & + & 1 & & & & + & + \\
\hline Arrhenatherum elatius & 3 & 4 & 5 & 6 & 9 & 5 & 2 & 4 \\
\hline Brachypodium pinnatum & + & 2 & 1 & 1 & + & + & + & \\
\hline Anthoxanthum odoratum & 2 & 1 & 2 & 1 & + & 2 & 2 & 1 \\
\hline Trisetum flavescens & 4 & 2 & 6 & 6 & 7 & 9 & 13 & 6 \\
\hline Briza media & 3 & 3 & 2 & 2 & 1 & 2 & + & + \\
\hline Grasses & 47 & 39 & 43 & 37 & 34 & 43 & 36 & 32 \\
\hline Trifolium repens & 9 & 12 & 15 & 17 & 20 & 12 & 16 & 25 \\
\hline Trifolium pratense & 5 & 9 & 7 & 7 & 10 & 6 & 12 & 8 \\
\hline Lotus corniculatus & 5 & 7 & 7 & 8 & 4 & 9 & 4 & 3 \\
\hline Medicago lupulina & + & 3 & + & & & & & \\
\hline Trifolium montanum & 1 & 2 & 1 & & 2 & & & \\
\hline Anthyllis vulneraria & & + & & & & & & \\
\hline Genista tinctoria & + & & & & & & & \\
\hline Legumes & 19 & 33 & 30 & 32 & 36 & 27 & 32 & 36 \\
\hline Chrysanthemum leucanthemum & 6 & 5 & 5 & 5 & 4 & 6 & 6 & 8 \\
\hline Stellaria graminea & + & + & + & + & + & + & + & + \\
\hline Veronica chamaedris & 2 & & + & + & & & & + \\
\hline Taraxacum officinale & 4 & 4 & + & 7 & 8 & 6 & 6 & 4 \\
\hline Cichorium intybus & 2 & & & & & & & \\
\hline Prunella vulgaris & 3 & 3 & 2 & 2 & 3 & 5 & 5 & 3 \\
\hline Colchicum autumnale & 1 & + & + & + & 2 & 3 & + & 2 \\
\hline Achillea millefolium & 4 & 3 & 3 & 3 & 1 & 1 & 1 & 1 \\
\hline Galium verum & 2 & 2 & 2 & + & + & + & 5 & 4 \\
\hline Rumexsp. & + & & & 1 & & + & + & + \\
\hline Campanulasp. & + & + & & + & & + & + & + \\
\hline Plantago media & 3 & 2 & 1 & 1 & 1 & 1 & 1 & 1 \\
\hline Ranunculus polyanthemus & + & + & + & 1 & + & + & + & + \\
\hline Filipendula bexapetala & 5 & 4 & 6 & 7 & 5 & 4 & 3 & 4 \\
\hline Knautia arvensis & + & + & & & & & & \\
\hline Carduus acanthoides & + & + & & & & + & & \\
\hline Carum carvi & + & + & + & + & + & + & + & + \\
\hline Tragopogon orientalis & + & + & + & & + & + & & + \\
\hline Thymus pannonicus & + & + & + & & + & + & + & + \\
\hline Carexsp. & + & + & & + & + & + & + & + \\
\hline Plantago lanceolata & + & 1 & 1 & 1 & 1 & 1 & 1 & 1 \\
\hline Rhinanthus rumelicus & + & + & + & + & 1 & 1 & 3 & 1 \\
\hline Alchemilla vulgaris & + & 1 & & + & + & + & + & + \\
\hline Plantago major & + & 1 & & 1 & 1 & 1 & 1 & 1 \\
\hline Potentilla reptans & + & & & + & & + & & \\
\hline Hypericum perforatum & & 1 & 1 & + & & & + & \\
\hline Gimnadenia odoratissima & & + & & + & & & & \\
\hline Trollius europea & & & & + & & & & \\
\hline Myosotis alpestris & & & & + & + & + & & + \\
\hline Forbs & 32 & 27 & 21 & 29 & 27 & 29 & 32 & 30 \\
\hline Species number & 43 & 40 & 33 & 37 & 33 & 36 & 34 & 35 \\
\hline
\end{tabular}




\section{References}

Belesky DP, Feldhake CM, Boyer DG (2002). Herbage Productivity and Botanical Composition of Hill Pasture as a Function of Clipping and Site Features. Agronomy Journal 94:351-358.

Braun-Blanquet (1964). Pflanzensoziologie, Grundzüge der Vegetationskunde. Springer-Verlag, Wien-New York, p. 865.

Dolek M, Gezer A (2002). Conserving biodiversity on calcareous grasslands in the Franconian Jura by grazing: a comprehensive approach. Biological Conservation 104(3):351-360.

Duelli P (1997). Biodiversity evaluation in agricultural landscapes: An approach at two different scales. Agriculture, Ecosystems and Environment 62(2-3):81-91.

Dumont B, Rook AJ, Coran Ch, Rover KU (2007). Effects of livestock breed and grazing intensity on biodiversity and production in grazing systems. Diet selection. Grass and Forage Science 62(2):159-171.

Elsaesser M, Kunz HG, Briemle G (2008). Strategy of organic fertilizer use on permanent grassland - results of a 22 -yearold experiment on meadow and mowing-pasture. Grassland Science in Europe 13:580-582.

Hector A, Loreau M (2005). Relationships between biodiversity and production in grasslands at local and regional scales. Grassland: A Global Resource, Editor McGilloway DA, 295-304.

Hopkins A, Pywell RF, Peel S, Johnson RH, Bowling PJ (1999). Enhancement of botanical diversity of permanent grassland and impact on hay production in Environmentally Sensitive Areas in the UK. Grass and Forage Science 54:163-173.

Isselstein J, Griffith BA, Pradel P, Venerus S (2007). Effects of livestock breed and grazing intensity on biodiversity and production in grazing systems. Nutritive value of herbage and livestock performance. Grass and Forage Science 62(2):145-158

Jeangros B (2002). Peut-on augmenter la diversité botanique d'une prairie permanente en supprimant la fumure?. Revue Suisse d'Agriculture 34(6):287-292.

Kopec M, Zarzycki J, Gondek K (2010). Species diversity of submontane grasslands: effects of topographic and soil factors. Polish Journal of Ecology 58(2):285-295.
Metera E, Sakowski T, Sloniewski K, Romanowicz B (2010). Grazing as a tool to maintain biodiversity of grassland-a review. Animal Science Papers and Reports 28(4):315-334.

Mosquera-Losada MR, Rodriguez-Barreira S, Lopez-Diaz ML, Fernandez-Nunez E, Rigueiro-Rodriguez A (2009). Biodiversity and silvopastoral system use change in very acid soils. Agriculture Ecosystems and Environment 131(34):315-324.

Nilsson FOL (2009). Biodiversity on Swedish pastures: Estimating biodiversity production costs. Journal of Environmental Management 90(1):131-143.

Peeters A, Maljean JF, Biala K, Bouckaert V (2004). Les indicateurs de biodiversité pour les prairies: un outil d'évaluation de la durabilité des systèmes d'élevage. Fourrages 178:217-232.

Rotar I, Păcurar F, Gârda N, Morea A (2010). The management of oligotrophic grasslands and the approach of new improvement methods. Romanian Journal of Grassland and Forage Crops 1:57-69.

Soder KJ, Rook AJ, Sandersen MA, Goslee SC (2007). Interaction of plant species diversity on grazing behavior and performance of livestock grazing temperate region pastures. Crop Science 47(1):416-425.

Tilman D, Wedin D, Knops J (1996). Productivity and sustainability influenced by biodiversity in grassland ecosystems. Nature 379(6567):718-720.

Vîntu V, Avarvarei I, Iacob T, Dumitrescu N, Samuil C (2003). Improvement of the degraded rangelands of the Romanian forest steppe by organic and mineral fertilization. Proc. of the VII-th International Rangelands Congress, Durban, South Africa 1267-1269.

Vîntu V, Samuil C, Sarbu C, Saghin Gh, Iacob T (2008). The influence of grassland management on biodiversity in the mountainous region of NE Romania. Proc of the $22^{\text {th }}$ General Meeting of the European Grassland Federation, Uppsala, Suedia, Grassland Science in Europe 13:183-185.

Weigelt A, Weisser WW, Buchmann N, Scherer-Lorenzen M (2009). Biodiversity for multifunctional grasslands: equal productivity in high-diversity low-input and low-diversity high-input systems. Biogeosciences 6(8):1695-1706. 